\title{
INSECTS
}

\section{THE DRAGONFLIES OF MANITOBA: AN UPDATED SPECIES LIST}

MARJORIE L. HUGHES, 110 Lanark Street, Winnipeg, MB R3N 1 L1 and JAMES R. DUNCAN Wildlife and Ecosystem Protection Branch, Manitoba Conservation, Box 24, 200 Saulteaux Crescent, Winnipeg, MB R3J 3 W3

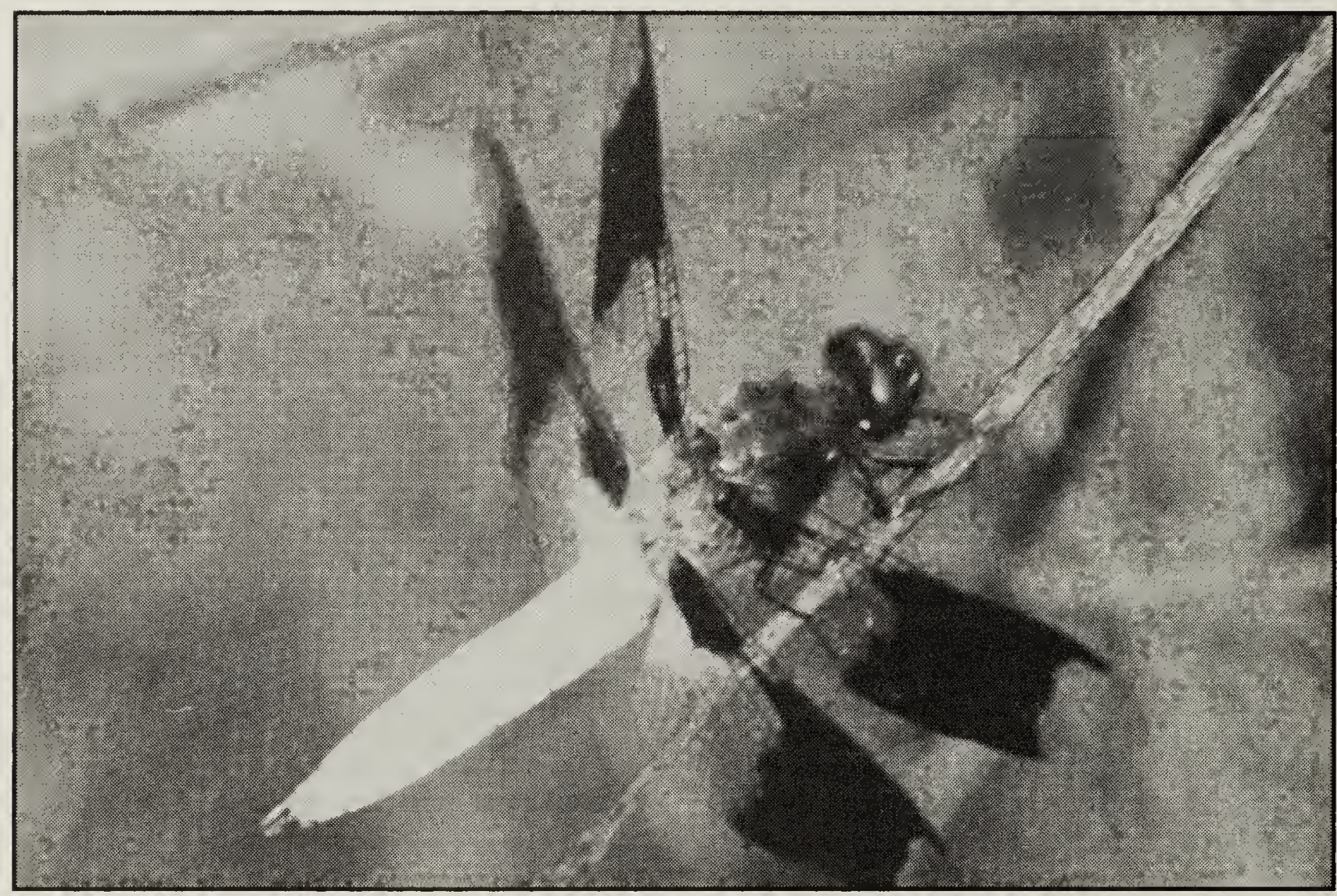

Figure 1. Common Whitetail, Libellula lydia

David P. Hughes

Dragonflies are some of our most familiar insects and the perfect animals for a naturalist to enjoy watching. (In this article the word dragonfly refers to the entire order Odonata, including those insects sometimes referred to as damselflies.) Their relatively large size, daytime habits and accessibility make dragonflies easy to observe. From the comfort of a lakeside deck chair, on a hot July afternoon, one can observe mature larvae crawling from the water and emerging into adults, and adult dragonflies patrolling and defending territories, courting, mating and even laying eggs. In spite of this, relatively little work has been done to determine the species present in various jurisdictions in
Canada, including Manitoba.

We are all indebted to the late Edmund M. Walker whose work on the dragonflies of Canada and Alaska resulted in many published articles and a valuable set of books, the latter completed by his colleague Philip Corbet. ${ }^{6,7.8}$ Walker visited Manitoba in 1913, 1921 and 1931. His visits were short and limited by such transportation as was available at the time. Even so, his contacts with local collectors such as Norman Criddle and J.B. Wallis allowed him to publish, in 1933, an account of 63 species for Manitoba. ${ }^{4}$ Walker subsequently published additional notes in $1941 .^{5}$ Manitoba was 
included in general insect surveys such as the Northern Insect Survey, the results of which were included in "The Odonata of Canada and Alaska". ${ }^{6,7,8}$ The next published Manitoba list was that of John Conroy and James Kuhn in conjunction with their study of water mites, the larvae of which parasitize dragonflies. ${ }^{2}$ Some collecting of dragonflies has occurred over the years and specimens have been deposited at the Manitoba Museum, the J.B. Wallis Collection at the University of Manitoba and elsewhere, but an update to the provincial species list seemed long overdue.

This report is the result of a study that began with the Manitoba Dragonfly Survey, a monitoring network established (by Jim Duncan) in 1999. Volunteers collected specimens for the survey from many sites in southern Manitoba and from The Pas, Flin Flon, Thompson and Churchill. The personal collection of Marjorie Hughes, which was begun in 1978, was incorporated into this study. Altogether, more than 1000 specimens have been identified and catalogued by the Manitoba Dragonfly Survey.

Recently, dragonflies were ranked according to their rarity in jurisdictions across Canada by the affiliated members of the National General Status Working Group under the auspices of the Canadian Endangered Species Conservation Council. ${ }^{9}$ A meeting of dragonfly experts from across Canada was held in Winnipeg October 9, 2002 to establish draft ranks for all species present in Canada. Ranking of species is helpful in prioritizing conservation efforts.
The present Manitoba list includes 95 species of dragonflies from nine families. New records are marked with an asterisk $\left.{ }^{*}\right)$. Abbreviations are used in the text for directions (n north, se southeast, cent for central etc.), col. for collector, MM for Manitoba Museum, CDC for Conservation Data Centre, Man for Manitoba and Prov. for Provincial. The nomenclature is based on the list of scientific and common names adopted by the Dragonfly Society of the Americas. ${ }^{3}$ After the name, each species is given a category of common, uncommon, rare or status uncertain. These are included to give observers a rough idea of whether they are likely or unlikely to encounter this species. A common species would be known from over 100 sites in the province and have a population size of over 10,000 individuals. A species listed as uncommon is known from about 21 to 100 occurrences with populations estimated at 3000 to 10,000 individuals. A rare species is known from less than 20 sites and populations are estimated at less than 3000 individuals. For several species, not enough information is known to make this assessment, so the category is given as "status uncertain." Some species are listed as accidental if the occurrence is well outside their normal range.

A species list should always be considered as a work in progress. As our knowledge of the dragonfly fauna increases, changes to this list will certainly be made. More collecting is needed in many geographic regions, especially the north, and in various habitat types. Plans are already underway for a comprehensive illustrated book on the dragonflies of Manitoba.

\section{DAMSELFLIES (Suborder Zygoptera)}

Jewelwings (Family Calopterygidae)

Calopteryx aequabilis Say - RIVER JEWELWING - common, s Man n to Grand Rapids.

C. maculata (Beauvois) - EBONY JEWELWING - rare (edge of range), extreme se Man, recorded once from Waugh. 
Spreadwings (Family Lestidae)

Lestes congener Hagen - SPOTTED SPREADWING - uncommon, s Man n to Grindstone Prov. Park.

L. disjunctus Selys - COMMON SPREADWING - common, $\mathrm{s}$ and cent Man $\mathrm{n}$ to Gillam.

L. dryas Kirby - EMERALD SPREADWING - common, $\mathrm{s}$ Man $\mathrm{n}$ to The Pas.

L. forcipatus Rambur - SWEETFLAG SPREADWING - status uncertain, s Man (this species is morphologically very similar to $L$. disjunctus, which leads to problems with identification).

L. inaequalis Walsh* - ELEGANT SPREADWING* - rare, e of Lee River 18-VII-1999 col. Ray Tuokko (10 CDC collection); Lyons Lake 16-VII-2001 col. Lance Barber (19 CDC collection).

L. rectangularis Say - SLENDER SPREADWING - uncommon, se Man to Winnipeg and Bird Lake.

L. unguiculatus Hagen - LYRE-TIPPED SPREADWING - common, s Man n to St. Laurent.

Pond Damsels (Family Coenagrionidae)

Amphiagrion saucium (Burmeister) - EASTERN RED DAMSEL - rare, Treesbank (Aweme), col. E. Criddle VI-1911 (J.B. Wallis Collection); bog near Gull Lake 8 VII 2000, col. J.R.

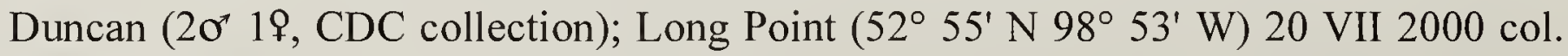
Terence Smith (10 19 CDC collection).

Chromagrion conditum (Selys) - AURORA DAMSEL - rare (edge of range), Ft. Whyte Centre, Winnipeg.

Coenagrion angulatum Walker - PRAIRIE BLUET - uncommon, sw Man, $\mathrm{n}$ to The Pas.

C. interrogatum (Selys) - SUBARCTIC BLUET - status uncertain, n Man: Long Point, The Pas, Wabowden.

C. resolutum (Selys) - TAIGA BLUET - common, records widespread from Emerson to Churchill.

Enallagma boreale Selys - BOREAL BLUET - common, s and cent Man to York Factory. E. carunculatum Morse - TULE BLUET - uncommon, se Man to Winnipeg and Bird Lake. E. civile (Hagen) - FAMILIAR BLUET - common, Red River Valley $n$ to Victoria Beach and e to Sandilands Prov. Forest.

E. clausum Morse - ALKALI BLUET - uncommon but abundant in scattered localities, sw Man $\mathrm{n}$ to Victoria Beach and The Pas.

E. cyathigerum (Charpentier) - NORTHERN BLUET - common, s and cent Man $n$ to Gillam.

E. ebrium (Hagen) - MARSH BLUET - common, s Man n to The Pas.

E. hageni (Walsh) - HAGEN'S BLUET - common, s Man n to The Pas.

Ischnura damula Calvert - PLAINS FORKTAIL - rare, Ft. Whyte Centre, Victoria Beach and Whiteshell Prov. Park.

I. perparva Selys - WESTERN FORKTAIL - rare, Ft. Whyte Centre, Winnipeg Beach.

I. posita (Hagen) - FRAGILE FORKTAIL - status uncertain, one specimen from Ft. Whyte Centre, 1976. ${ }^{2}$

I. verticalis (Say) - EASTERN FORKTAIL - fairly common, se Man to Winnipeg and Victoria Beach.

Nehalennia irene (Hagen) - SEDGE SPRITE - common, s and cent Man n to The Pas.

DRAGONFLIES (Suborder Anisoptera)

Darners (Family Aeshnidae)

Aeshna canadensis Walker - CANADA DARNER - common, $\mathrm{s}$ and cent Man $\mathrm{n}$ to Wabowden. A. constricta Say - LANCE-TIPPED DARNER - common, s Man $\mathrm{n}$ to Dauphin. 
A. eremita Scudder - LAKE DARNER - common, s and cent Man n to York Factory.

A. interrupta Walker - VARIABLE DARNER - common throughout Man $\mathrm{n}$ to about $56^{\circ} \mathrm{N}$. A. juncea (Linnaeus) - SEDGE DARNER - status uncertain, from se corner of Man $\mathrm{n}$ to Churchill.

A. septentrionalis Burmeister - AZURE DARNER - status uncertain, extreme $\mathrm{n}$ along the Hudson Bay coastline.

A. sitchensis Hagen - ZIGZAG DARNER - common, from Tolstoi and Star Lake n to Churchill.

A. subarctica Walker - SUBARCTIC DARNER - uncommon, records from Star Lake to The Pas.

A. tuberculifera Walker* - BLACK-TIPPED DARNER* - rare, Narcisse (pond) VI-1993 col. "TAC/TCG" (19 J.B. Wallis Collection); Star Lake, (Whiteshell Prov. Park) 29-VII2001 col. D.R.Collicutt (10' CDC collection).

A. umbrosa Walker - SHADOW DARNER - common, widespread in s and cent Man to Churchill.

Anax junius (Drury) - COMMON GREEN DARNER - common throughout s Man $\mathrm{n}$ to about $50^{\circ} \mathrm{N}$.

Basiaeschna janata (Say) - SPRINGTIME DARNER - uncommon in extreme se corner of Man, Whiteshell Prov. Park and Pinawa.

Boyeria vinosa (Say) - FAWN DARNER - uncommon, occurs only in extreme se corner of Man, all records are within Whiteshell Prov. Park.

Clubtails (Family Gomphidae)

Arigomphus cornutus (Tough) - HORNED CLUBTAIL - uncommon, se Man and w to Winnipeg, Red River and La Salle River.

Dromogomphus spinosus Selys* - BLACK-SHOULDERED SPINYLEG* - rare (edge of

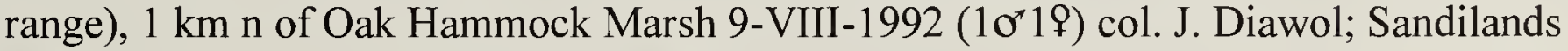
Prov. Forest $2 \mathrm{~km}$ e of Marchand 3-VII-1993 (1 $\left.\sigma^{\star}\right)$ col. J. Diawol (specimens in J.B. Wallis Collection).

Gomphus exilis Selys - LANCET CLUBTAIL - uncommon, se Man from Lyons Lake to Berens River.

G. externus (Hagen in Selys) - PLAINS CLUBTAIL - uncommon but may be abundant in scattered localities, Red River valley $\mathrm{n}$ to Winnipeg Beach, Assiniboine River w to Treesbank.

G. fraternus (Say) - MIDLAND CLUBTAIL - fairly common along Winnipeg River and Lake Winnipeg $\mathrm{n}$ to Berens River. Manitoba also has a distinctive smaller pale type of this species which Walker recognized as subspecies G. fraternus manitobanus. ${ }^{7}$ It was found on the Red River at Winnipeg and on the Assiniboine River at Treesbank.

G. graslinellus Walsh - PRONGHORN CLUBTAIL - rare, across s Man to about $50^{\circ} 10^{\prime} \mathrm{N}$. G. spicatus Hagen in Selys - DUSKY CLUBTAIL - rare to uncommon due to limited range, extreme se Man, Whiteshell and Nopiming Prov. Parks.

G. vastus (Walsh)* - COBRA CLUBTAIL* - rare, Jessica Lake, Whiteshell Prov. Park. 6VII-1953 col. R.D.Bird (29 J.B. Wallis collection); Silver Falls (Winnipeg River) 13-VII2000 col. John Markert (29 CDC collection).

Hagenius brevistylus Selys - DRAGONHUNTER - common, se Man n to Berens River.

Ophiogomphus colubrinus Selys - BOREAL SNAKETAIL - fairly common, from se Man to Gillam.

O. rupinsulensis (Walsh) - RUSTY SNAKETAIL - uncommon, across s Man $\mathrm{n}$ to about $50^{\circ} 10^{\prime} \mathrm{N}$.

Stylurus notatus (Rambur) - ELUSIVE CLUBTAIL - rare, s Man n to The Pas. 
Spiketails (Family Cordulegastridae)

Cordulegaster maculata Selys* - TWIN-SPOTTED SPIKETAIL* - rare (edge of range), se Man, Sandilands Prov. Forest 17-VI-1989 (107) col. R.N. Brandt; 7-VI-1990 (19) col. T.D. Galloway/ "DCH/ACT". An exuvia from Falcon Lake 23-VI-1991 col. T.D. Galloway (all specimens in J.B. Wallis Collection).

\section{Cruisers (Family Macromiidae)}

Didymops transversa (Say)* - STREAM CRUISER* - uncommon, limited distribution in se Man, collected from May 22 to June 29 by several collectors (M.L. Hughes, D.R. Collicutt, G. Vidal and L. Barber - Whiteshell and Nopiming Prov. Parks $\left(11 \sigma^{\top}, 49\right.$ specimens in CDC and MM collections).

Macromia illinoiensis Walsh - ILLINOIS RIVER CRUISER - rare to uncommon due to limited distribution, se Man n to Berens River.

\section{Emeralds (Family Corduliidae)}

Cordulia shurtleffii Scudder - AMERICAN EMERALD - common throughout Man.

Dorocordulia libera (Selys)* - RACKET TAILED EMERALD* - uncommon, Hansen Creek 11-VII-1978 col. T.D. Galloway, (J.B. Wallis Collection); Winnipeg, 9-VI-2001 col. H. Mueller; Star Lake, 4-VI-2000 col. D.R. Collicutt; Lyons Lake 8-VII-2001 col. L. Barber; w of Pinawa 17-VI-1999 col. J.R. Duncan; Rabbit River; Nopiming Prov. Park, 22-VI-2001 col. G. Vidal (30 , 69, specimens in CDC collection).

Epitheca canis (McLachlan) - BEAVERPOND BASKETTAIL - uncommon, Whiteshell Prov. Park and Sandilands Forest Reserve, also Riding Mountain National Park, Dauphin and Swan River.

Epitheca cynosura (Say)* - COMMON BASKETTAIL* - rare (edge of range), near se border, West Hawk Lake 1-VII-1989 col. A.J. Mackay (19 J.B. Wallis collection); Star Lake 10-VII-1999 col. D.R. Collicutt and Lyons Lake 7-VII-2001 col. L. Barber (20' CDC collection).

E. spinigera (Selys) - SPINY BASKETTAIL - common, s and cent Man to Flin Flon.

Somatochlora albicincta (Burmeister) - RINGED EMERALD - status uncertain, recorded at Churchill, probably widespread in n Man.

S. cingulata (Selys) - LAKE EMERALD - status uncertain, recorded from Gillam and other points $n$, probably widespread in $n$ Man.

S. ensigera Martin - PLAINS EMERALD - rare to uncommon, s Man, recorded at Lockport, Starbuck, McCreary, Onah, Westbourne and Brokenhead River.

S. forcipata (Scudder) - FORCIPATE EMERALD - status uncertain, recorded only from The Pas, probably occurs across n Man.

S. franklini (Selys) - DELICATE EMERALD - common, widespread in Man.

S. hudsonica (Hagen in Selys) - HUDSONIAN EMERALD - status uncertain, recorded from Norway House and Churchill, probably widespread in n Man.

S. kennedyi Walker - KENNEDY'S EMERALD - uncommon, recorded from Winnipeg n to Norway House.

S. minor Calvert in Harvey - OCELLATED EMERALD - status uncertain, recorded from s Man $n$ to Gillam.

S. septentrionalis (Hagen) - MUSKEG EMERALD - status uncertain, a species of the far north, recorded from Churchill.

S. walshii (Scudder) - BRUSH-TIPPED EMERALD - rare to uncommon, recorded from Winnipeg, Star Lake and Dauphin, expected to occur n to tree line.

S. whitehousei Walker - WHITEHOUSE'S EMERALD - status uncertain, recorded at Churchill, probably widespread in n Man. 
S. williamsoni Walker - WILLIAMSON'S EMERALD - rare, limited distribution in se Man, recorded from Winnipeg Beach, Gull Lake and Pinawa.

Williamsonia fletcheri Williamson - EBONY BOGHAUNTER - rare, se Man, recorded from "Lake Winnipeg" in 1890. ${ }^{8}$ Rediscovered at Agassiz Prov. Forest 20 \& 22-V-1980 col. T.D. Galloway (10"19 J.B. Wallis Collection).

Skimmers (Family Libellulidae)

Leucorrhinia borealis Hagen - BOREAL WHITEFACE - fairly common, s Man n to The Pas.

L. frigida Hagen - FROSTED WHITEFACE - fairly common, se Man, s Interlake area.

L. glacialis Hagen - CRIMSON-RINGED WHITEFACE - fairly common, s. Man.

L. hudsonica (Selys) - HUDSONIAN WHITEFACE - common, widespread in all of Man.

L. intacta (Hagen) - DOT-TAILED WHITEFACE - common, s Man n to Dauphin.

L. patricia Walker - CANADA WHITEFACE - status uncertain, n Man recorded from Gillam and Churchill.

L. proxima Calvert - RED-WAISTED WHITEFACE - common throughout Man.

Libellula julia Uhler - CHALK-FRONTED CORPORAL - common, s Man $\mathrm{n}$ to Swan River.

L. luctuosa Burmeister* - WIDOW SKIMMER* - rare or accidental (edge of range), one record from n Winnipeg, $31-$ VII-1983 col. D. Pollock (1 ơ J.B. Wallis Collection).

L. lydia Drury* - COMMON WHITETAIL* - (see Figure 1) - rare (edge of range), first record in Winnipeg in 2001 col. J.R. Duncan (10" in CDC collection). Additional records: Ste. Adolphe, 30-VI-2002 reported by Andy Courcelles; La Salle River at La Barriere Park, 13-VIII-2002, col. M.L. Hughes (10 in CDC collection). Recent sightings indicate that it may be expanding its range into $\mathrm{S}$ Man.

L. pulchella Drury - TWELVE-SPOTTED SKIMMER - (see Figure 2) - common, s Man n to about $51^{\circ} \mathrm{N}$.

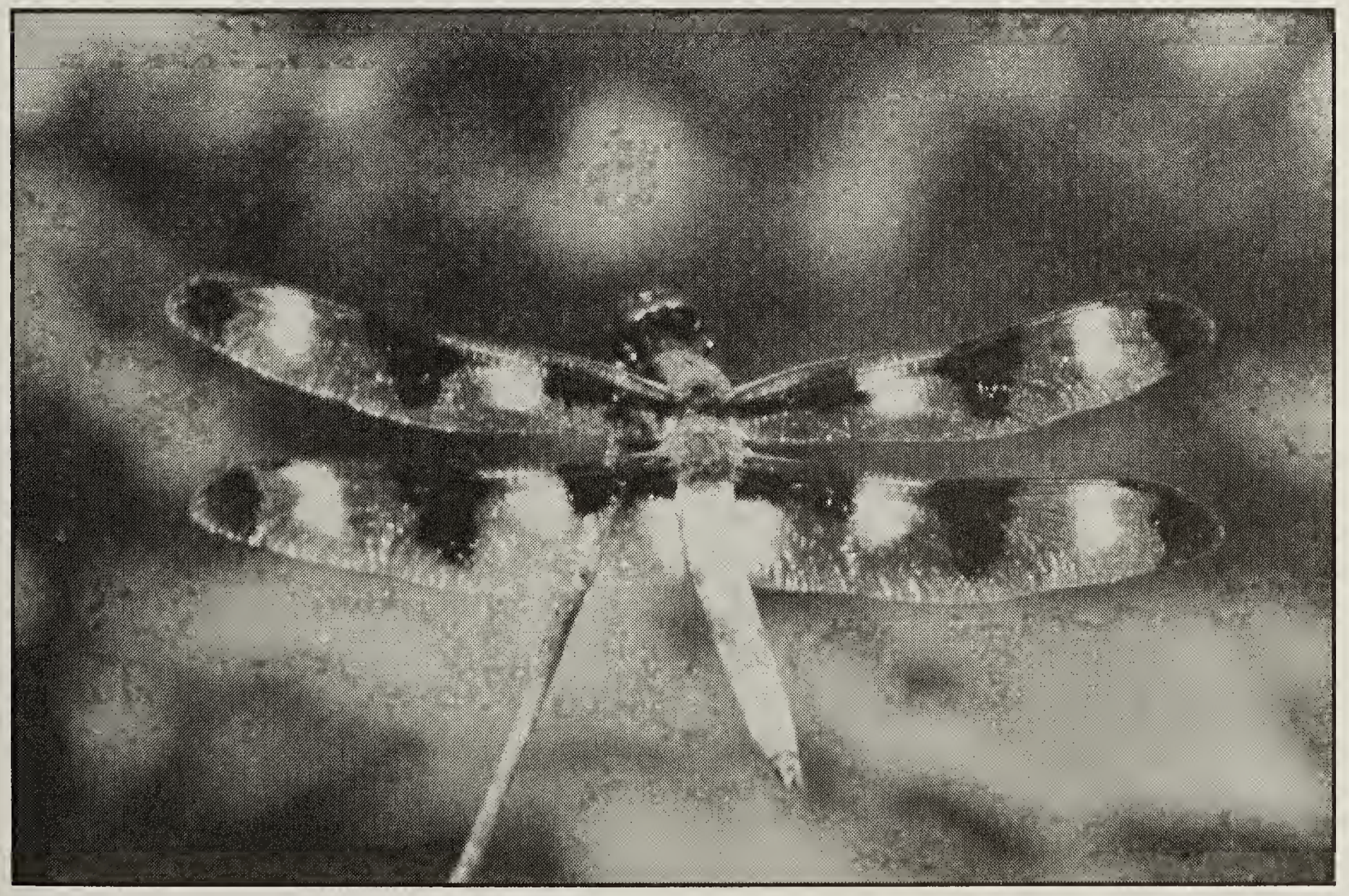


L. quadrimaculata L. - FOUR-SPOTTED SKIMMER - common, s Man n to The Pas.

Pachydiplax longipennis (Burmeister) - BLUE DASHER - rare, one record from Lac du Bonnet. $^{8}$

Pantala flavescens (Fabricius) - WANDERING GLIDER - rare, a migratory species, range includes s Man n to Gimli.

P. hymenaea (Say) - SPOT-WINGED GLIDER - rare, a migratory species, only two records, Gimli and Victoria Beach.

Sympetrum corruptum (Hagen) - VARIEGATED MEADOWHAWK - common, s Man to The Pas.

S. costiferum (Hagen) - SAFFRON WINGED MEADOWHAWK - common, s Man n to The Pas.

S. danae (Sulzer) - BLACK MEADOWHAWK - common, s Man n to Wabowden.

S. internum Montgomery - CHERRY-FACED MEADOWHAWK - common, s Man n to The Pas.

S. madidum (Hagen) - RED-VEINED MEADOWHAWK - rare, w Man $\mathrm{n}$ to about $54^{\circ} \mathrm{N}$. S. obtrusum (Hagen) - WHITE-FACED MEADOWHAWK - common, s Man n to The Pas. S. semicinctum (Say)* - BAND-WINGED MEADOWHAWK* - rare (edge of range), s Man: Spirit Sands, Spruce Woods Prov. Park, 21-VIII-1999 (1 $\left.\sigma^{*}\right)$ col. J.R. Duncan; Star Lake 2-IX-2001 (1 (') col. D.R. Collicutt; N.W.Angle Prov. Forest 28-VIII-2001 (19) col. C. Hamel and E. Reimer (all specimens in CDC collection).

S. vicinum (Hagen)* - YELLOW-LEGGED MEADOWHAWK* - rare (edge of range), se Man, Wallace Lake (Nopiming Prov.Park)12-VIII-2001 col. L. Pelletier (1 ơ 19CDC collection).

Previous lists for Manitoba included the Green-striped Darner (Aeshna verticalis), Cardinal Meadowhawk (Sympetrum illotum) and Ruby Meadowhawk (Sympetrum rubicundulum). We have not been able to locate specimens to confirm these records and have concluded that they were reported erroneously. The Cardinal Meadowhawk is known in Canada only from British Columbia's south coast. ${ }^{1,8} \mathrm{New}$ research regarding the genus Sympetrum has made it easier to identify the difficult little red meadowhawks, including Sympetrum rubicundulum. ${ }^{1}$ The reason for the previous report may be that the Ruby Meadowhawk is extremely difficult to distinguish from Cherry-faced and White-faced Meadowhawk unless the identifier is familiar with these species and has access to good references. Similarly, the Green-striped Darner is difficult to distinguish from the Canada Darner. The Green-striped Darner is known only from southern Ontario and the Maritime provinces. ${ }^{7}$
In many cases, species are rare in the province only because Manitoba is at the extreme edge of their natural range. Rarity in Manitoba is less of a concern for species common in their natural range outside the province. This applies to those noted above by the comment "edge of range". The Elegant Spreadwing and Cobra Clubtail, on the other hand, are at the edge of their natural range but are considered uncommon in other areas of Canada also. The record for the Blue Dasher is historic. ${ }^{8}$ It is a southern species which reaches only the southern extremes of Canada and the Manitoba record may be an accidental occurrence. The Red-veined Meadowhawk is a western species with a few historical records from western Manitoba. It is fairly uncommon throughout its range. The Wandering Glider and Spotwinged Glider are migratory species which visit Manitoba occasionally but they cannot definitely be considered resident in the province. The Plains Forktail and Western Forktail are showing up in large numbers in 
Alberta in gravel pits and other anthropogenic habitats. Manitoba studies of similar habitats are needed to determine the status of these species. The Pronghorn Clubtail is not common anywhere in Canada, hence closer monitoring of the Manitoba population is warranted. The Elusive Clubtail is common only on the Ottawa River and the population in Manitoba requires further study. Far too little is known of all the species of Striped Emeralds (the genus Somatochlora). This is due, in many cases, to their northern distribution and their association with northern lakes and peatlands. The Plains Emerald is known only from Midwestern states and provinces, and thus its rarity in Manitoba is of special concern. The Ebony Boghaunter is considered rare or uncommon in all provinces where it occurs (Manitoba to the Maritimes), but this may be due to its very secretive habits. Its bog habitat is common enough to consider it to be at little risk.

\section{Acknowledgements}

Funding for the study leading to this article was provided to the first author by the Dragonfly Assessment Project through Manitoba Conservation. This study could not have been completed without the participation of all those who have collected and submitted specimens to the Manitoba Dragonfly Survey, the J.B. Wallis Collection and the Manitoba Museum collection.
Although some collectors are named in the text above, we owe thanks to all collectors because every contribution is important. Special thanks are owing to Terry Galloway for assisting with access to the J.B. Wallis Collection. Thanks also to Robert Nero for reviewing earlier drafts of this paper. Many thanks to David Hughes for allowing us to use his beautiful photographs of dragonflies.

1. CARLE, F.L. 1993. Sympetrum janeae spec.nov. from eastern North America with a key to nearctic Sympetrum. Odonatologica 22(1): $1-16$.

2. CONROY, J. and J.L. KUHN.1977. New annotated records of Odonata from the province of Manitoba with notes on their parasitism by larvae of water mites. Manitoba Entomologist 11: 27-40.

3. DRAGONFLY SOCIETY OF THE AMERICAS Web Site. Available: http://www.ups.edu/biology/museum/ NAdragons.html Accessed January 2003.

4. WALKER, E.M. 1933. The Odonata of Manitoba. The Canadian Entomologist 65: 57-72.

5. WALKER, E.M. 1941. New records of Odonata from Manitoba. The Canadian Entomologist 73: 35-36.

6. WALKER, E. M. 1953. The Odonata of Canada and Alaska. Volume 1.University of Toronto Press, Toronto.

7. WALKER, E. M. 1958. The Odonata of Canada and Alaska. Volume 2 . University of Toronto Press, Toronto.

8. WALKER, E. M. and P.S. CORBET. 1975. The Odonata of Canada and Alaska. Volume 3. University of Toronto Press, Toronto.

9. WILD SPECIES 2000: The General Status of Species in Canada ) http://www.wildspecies.ca

"A butterflier and a birder are linked in their love of flying creatures. Flying creatures, in turn, are linked by their ability to take to the air, a feat much admired in native cultures. The Ogala Lakota grouped flying creatures together, calling them 'Winged Peoples' and associated them all with the powers of the wind. Included in this group were birds, butterflies, moths and dragonflies - the latter venerated because of their ability to escape a blow." 